Scholarship Repository

University of Minnesota Law School

Articles

Faculty Scholarship

1989

\title{
Major Developments at the 1989 Session of the UN Commission on Human Rights
}

\author{
Reed Brody \\ David Weissbrodt \\ University of Minnesota Law School, weiss001@umn.edu
}

Follow this and additional works at: https://scholarship.law.umn.edu/faculty_articles

Part of the Law Commons

\section{Recommended Citation}

Reed Brody and David Weissbrodt, Major Developments at the 1989 Session of the UN Commission on Human Rights, 11 Hum. RTs. Q. 586 (1989), available at https://scholarship.law.umn.edu/faculty_articles/ 411.

This Article is brought to you for free and open access by the University of Minnesota Law School. It has been accepted for inclusion in the Faculty Scholarship collection by an authorized administrator of the Scholarship Repository. For more information, please contact lenzx009@umn.edu. 


\section{Major Developments at the 1989 Session of the UN Commission on Human Rights}

Reed Brody and David Weissbrodt*

On 10 March 1989 the United Nations Commission on Human Rights concluded its six week session in Geneva with a number of significant decisions as to country situations in which human rights violations have occurred, including the establishment of a Special Rapporteur on Romania. The Commission also continued monitoring disappearances, torture, executions, religious intolerance, and mercenaries; approved a draft Convention on the Rights of the Child after nine years of discussion; promptly transmitted to the General Assembly a draft Second Optional Protocol to the International Covenant on Civil and Political Rights for the abolition of the death penalty; reaffirmed the right of conscientious objection to military service; renewed emphasis on the provision of advisory services to assist governments in protecting the rights of their citizens; and acted on a number of other matters. ${ }^{1}$

The Commission session was marred, however, by the failure to take any action on human rights abuses in Iraq or even to discuss human rights in Africa (outside of Southern Africa). The Commission also refused to seek greater scrutiny of the human rights situation in Cuba, despite strenuous lobbying by the United States delegation.

\section{ORGANIZATION AND CONDUCT OF THE COMMISSION SESSION}

At its first meeting on 30 January 1989 the forty-three member governments of the Commission elected Marc Bossuyt of Belgium as Chair for the 45th

* This article is adapted from one which appeared in IC/ Review 42 (June 1989).

1. See Quaker United Nations Office-Geneva, United Nations Commission on Human Rights, 45th Session, 30 Jan. to 10 Mar. 1989 (1989); see generally Howard Tolley, Jr., The U.N. Commission on Human Rights (Boulder: Westview Press, 1987). 
session, pursuant to the five year rotational system which this year called for a chair from the "Western European and Other" group of countries. ${ }^{2}$ The Commission also elected Christy Ezim Mbonu (Nigeria) as its Rapporteur and the three other members of its Bureau: Claude Heller (Mexico), Quian jiadong (China), and Zagora Ilic (Yugoslavia) as vice-presidents. The election of Mr. Quian broke a long-standing tradition that representatives of the permanent members of the UN Security Council would not sit on the bureau of the Human Rights Commission or other functional commissions of the UN Economic and Social Council; his election fueled speculation that China would seek to become Chair at next year's Commission session.

The Commission heard speeches from an unusually large number of cabinet officials, which continued a trend from the past two sessions and which made the Commission appear less like a specialized human rights body and more like the General Assembly. The cabinet officials, who spoke at the 1989 session, included Michel Rocard, Prime Minister of France; Dante Caputo, Foreign Minister of Argentina and President of the UN General Assembly; F. Fernandez Ordonoz, Foreign Minister of Spain, who spoke as chairman of the European Community Council of Ministers; the Vice-President of Afghanistan; and the Foreign Ministers of the Holy See and Sweden. Rocard was eloquent in his praise for nongovernmental organizations (NGOs): "When states keep silent, the NGOs speak. When governments are powerless, NGOs act, unfettered by reasons of state. That is when the oppressors hesitate, the oppressed resist and the excluded regain hope."

\section{COUNTRY SITUATIONS}

The Commission on Human Rights took action on a variety of country situations and received significant information about human rights abuses in an even wider group of nations, but experienced increasing difficulty in taking action on some countries which received political support from strengthened regional blocs. The Commission adopted resolutions, discussed below, on Afghanistan, Albania, Burma, Chile, Cuba, El Salvador, Guatemala, Haiti, Iran, Israeli-occupied territories, Southern Lebanon, Romania, and South Africa. The Commission also adopted resolutions on Equitorial Guinea, Kampuchea, Namibia, and Western Sahara. In addition, the Commission continued its scrutiny of Brunei, Haiti, Paraguay, and Somalia, under the confidential procedure authorized by Economic and Social Council Reso-

2. The Western European and Other Group of countries in the Commission includes Belgium, Canada, France, the Federal Republic of Germany, Portugal, Spain, Sweden, the United Kingdom, and the United States.

3. M. Rocard, Speech to UN Commission on Human Rights, 6 Feb. 1989, at 4. 
lution $1503 .{ }^{4}$ The Commission failed to take action on Iraq either in public session or under the confidential " $1503^{\prime \prime}$ procedure and also discontinued its consideration under "1503" of Honduras, Syria, and Zaire. ${ }^{5}$ Once again the Commission postponed any decision on the situation in a divided Cyprus. A far broader group of countries were the subject of scrutiny by the Commission under the thematic procedures discussed below.

Action on country situations at the Commission has become increasingly difficult with the strengthening of regional blocs which are able to prevent or control measures sought to be taken against one of the region's governments. This problem has long undermined Commission initiatives in Africa (outside of Southern Africa) and has recently become evident in Latin America where the "Group of $8^{\text {"6 }}$ now effectively determines the limits of resolutions on Chile, El Salvador, and Guatemala. According to several Latin diplomats, this trend towards regionalization was accelerated by the US campaign against Cuba which, in the words of one, "made us realize that this is a political forum, not a human rights forum, and we had to develop a political response." The Asian group in the Commission had long been divided by a great diversity of economic systems, cultures, languages, and forms of government represented in that continent. Nevertheless, the Asian group coalesced at the 1989 session of the Commission to limit substantially a French initiative on Burma. In contrast, the Commission's resolution on Romania was made possible because Bulgaria, the German Democratic Republic, the Ukrainian SSR, and the USSR decided not to participate in that vote.

\section{Afghanistan}

The Commission received a brief report on the human rights situation in Afghanistan from its Special Rapporteur, who had received cooperation from the Afghan authorities and had been permitted to visit the country. The Commission, without a vote, adopted a resolution welcoming the cooperation of the Afghan authorities and urging all parties concerned to work for a comprehensive political solution based on the right of self-determination. Following its approach at the 1988 General Assembly, the USSR joined the consensus on the resolution rather than forcing a vote which would have been overwhelming. The Commission urged all parties to the conflict to release all prisoners of war in accordance with humanitarian law and to do

4. E.S.C. Res. 1503, 48 U.N. ESCOR Supp. (No. 1A) at 8, U.N. Doc. E/4832/Add. 1 (1970).

5. It appears, however, that Zaire will report on its human rights situation in a closed meeting during the 1990 session of the Commission.

6. The "Group of 8 " comprise the eight Latin American members of the Commission: Argentina, Brazil, Columbia, Cuba, Mexico, Panama, Peru, and Venezuela. 
everything possible to facilitate the safe return of refugees and displaced persons in safety. It called again upon the Afghan authorities to investigate the fate of disappeared persons.

\section{Albania}

Last year the Commission decided to transfer its consideration of Albania from the confidential 1503 procedure to a public consideration under agenda item 12 (the "Question of the violation of human rights and fundamental freedoms in any part of the world ...")..$^{7}$ In 1988 the Commission also recommended to the Economic and Social Council (ECOSOC) the release of all records about Albania which accumulated under the 1503 procedure over a five year period during which that government had refused to respond. By a close vote $\mathrm{ECOSOC}$, however, rejected the recommendation to make public the 1503 materials on Albania. Hence, despite last year's decision, there was no reference to Albania in the agenda of the 1989 session. The Commission did receive a resolution on Albania from its Sub-Commission on Prevention of Discrimination and Protection of Minorities. On a Portuguese initiative, the Commission adopted (by a vote of thirty-three in favor, three against, and thirteen abstentions) a resolution regretting that the exhaustive efforts to solicit the cooperation of Albania under the 1503 procedure had been in vain and also that the government had failed for the second consecutive year to respond to allegations submitted by the Special Rapporteur on Religious Intolerance. The Commission called upon the government to provide information on the concrete manner in which its constitutional and legal measures complied with the provisions of the Universal Declaration of Human Rights and to respond to the allegations transmitted by the Special Rapporteur. The Commission's consideration of the situation in Albania was handicapped by the lack of timely and adequate information about conditions in the country.

\section{Burma}

The Commission also was handicapped by insufficient information about the current human rights situation in Burma. The French delegation proposed a draft resolution which sought the appointment of a Special Rapporteur to assess the situation. The French proposal met with strong resistance from the Asian delegates. After long negotiations, the Commission without a vote adopted a compromise decision, submitted by the Chair, expressing "concern

7. C.H.R. Res. 1988/17, ESCOR Supp. (No. 2) at 66, U.N. Doc. E/CN.4/1988/88 (1988). 
$\ldots$ at the reports and allegations of violations of human rights in Burma in $1988^{\prime \prime}$ and encouraged the Burmese authorities to fulfill their promises of holding elections.

\section{Chile}

Once again the Commission expressed its concern at the persistence of serious violations of human rights in Chile, as described in the comprehensive report of the Special Rapporteur, which referred to cases of murder, abduction, disappearances, torture, arbitrary arrest, prolonged periods of incommunicado detention, political prisoners, death threats, and the intimidation of opponents of the government. Despite the abstention of Japan, the United States, and eight developing countries, the Commission again urged the government to put an end to these human rights abuses and to continue adopting measures to permit the restoration of the rule of law in Chile and the full enjoyment of human rights.

\section{Cuba}

The most politically-charged debate at the 1989 session arose over the attempt by the United States to continue the Commission's intensive scrutiny of the human rights situation in Cuba. At its 1988 session the Commission had accepted an invitation from the government of Cuba for a delegation of six Commission members to visit that country and "prepare a report to be submitted for consideration by the Commission, which would decide on the manner in which the report was to be examined." ${ }^{\prime 9}$

The Commission's delegation included the chair of the 1988 session, Alioune Sene of Senegal, as well as J. S. Attah (Nigeria), Todor Dichev (Bulgaria), Jose Ingles (Philippines), Michael Lillis (Ireland), and Rafael Rivas Posada (Colombia). The group had initially scheduled a visit of five days, which was extended to ten days in September 1988, during which it met with government officials, NGOs, and private individuals. The group also visited prisons (and met in private with prisoners), schools, hospitals, and other facilities. The Cuban government publicized the trip and published the telephone numbers at which the group could be contacted, with the result that the group received over 1,600 complaints alleging human rights violations.

8. C.H.R. Res. 1989/11, U.N. Docs. E/CN.4/1989/2.11/Add. 10, at 3 (1989); E/CN.4/1989/ L.10/Add. 12, at 11 (1989).

9. See Weissbrodt, Country Related and Thematic Developments at the 1988 Session of the UN Commission on Human Rights, 10 Hum. Rts. Q. 544, 550-58 (Nov. 1988). 
When the Commission began its 1989 session, the carefully negotiated report had not yet been completed. Since the 1988 Commission had failed to decide how (or even whether) the report would be considered by the 1989 session of the Commission, it was feared that a procedural struggle might erupt over the agenda on the very first day of the 1989 session. The United States made clear, as it had last year, that it wanted the discussion to take place under agenda item twelve (violation of human rights and fundamental freedoms). The Cuban delegation and their Latin American allies were equally insistent that Cuba could not be compared to other countries on the Commission's agenda under item twelve, such as Afghanistan, El Salvador, and Iran; they proposed discussing the report under item 11 (further promotion and encouragement of human rights and fundamental freedoms). Negotiations were undertaken by Michael Lillis (Ireland) and Mercedes Rico (Spain), for the Western European and Other group, on the one hand, and by Claude Heller (Mexico), Rafael Rivas Posada (Colombia), and Manuel Rodriguez (Peru), for the Latin "Group of 8 ," on the other. The compromise solution was to deal with the report under a separate, special item eleven bis, sparing Cuba from item twelve treatment, but permitting a full debate by Commission members and observers.

The report itself, finally released at the end of the Commission's third week, provided an extremely interesting picture of conditions in Cuba. ${ }^{10}$ The document issued by the group which visited Cuba ran 400 pages and was apparently the largest human rights report ever produced under United Nations auspices. The document, however, contained only fifty-five pages of actual text in which the group summarized the allegations of human rights violations received by the group and the government's responses. The remainder of the document comprised a series of annexes mostly containing allegations of human rights violations. One annex listed by category 1,600 complaints received by the group of which 1,183 concerned the right to leave the country or to return. Another annex reproduced the questions on the Cuban constitutional and legal system prepared by Ambassador Lillis on behalf of the group. Several annexes reproduced articles and allegations by opponents of the Cuban government. The document also included tables showing the gains in the enjoyment of economic, social, and cultural rights which have occurred since the Cuban revolution of 1961.

The report was remarkable in that it was adopted by consensus of all six Commission members from different parts of the world, including the Bulgarian member representing the Eastern European countries. Evidently, the consensus nature of the report made it impossible for the group to reach any conclusions, because the report lacked both factual findings and recommendations. A careful reading of the allegations of human rights violations

10. U.N. Doc. E/CN.4/1989/46 (1989). 
and the government's responses did indicate recent improvements in that a number of prisoners had been released, prison conditions had improved, and complaints of ill-treatment of prisoners had diminished. The principal remaining problems dealt with the right of Cubans to leave their country or return. Cuba did not respond to many of the individual allegations mentioned in the document and the group was not able to study these cases.

The United States in 1988 had contended that there were 10,000 to 15,000 political prisoners in Cuba, extrajudicial executions, and disappearances. The report did not substantiate these allegations, although they were repeated less stridently by the US delegation to the 1989 Commission session. Most disturbing, however, were reports that the Cuban government had retaliated against some individuals who gave evidence to the group or sought to do so. The US delegation left no doubt that its highest, if not sole, priority for the 1989 Commission was achieving a condemnation of Cuba, but the delegation did not repeatedly present public statements throughout the session, as occurred in 1988. US lobbying, while reportedly as intense as in 1988 in the capitals of the voting members of the Commission, was somewhat less visible in the Commission and its corridors. While Cuba remained largely a US concern as in 1987 and 1988, this year several other countries joined the US initiative, including Morocco, the Netherlands, and the United Kingdom.

The United States had four concrete objectives regarding Cuba at the 1989 Commission:

(1) to continue the mandate of the group of six who visited Cuba;

(2) to ask the group of six to continue to observe the human rights situation in Cuba pursuant to agenda item twelve (violation of human rights);

(3) to ask the group to investigate the individual allegations which had been presented to the group and the allegations of retaliation against some witnesses or prospective witnesses; and

(4) to encourage the Cuban government to accept a second visit.

These objectives were embodied in a draft which the US delegation circulated informally. One of the principal arguments in favor of the US position was that the Cuban government had not received an opportunity to respond fully to the group's report, which had just been produced, and thus the group needed to continue its consideration of the information it had received and the Cuban response.

The Cuban government sought to remove this argument by presenting a lengthy oral response to the report during the discussion under agenda item eleven bis. Cuban Ambassador, Raul Roa Kouri, spent almost ninety minutes providing his government's answers to allegations contained in the report. Debate on the report then generally followed geopolitical lines. The Western European delegates asserted that the report showed evidence of grave violations even if, in the words of the Portuguese delegate, "the picture of Cuba ... was certainly not comparable with the human rights situations 
in some other countries where the number of killings, disappearances, and forms of torture, raised the question of the individual State's capacity to maintain law and order and respect for human rights." ${ }^{\prime 1}$ To the United Kingdom, the report showed that "an all-powerful and oppressive party machine dominated all aspects of public and private life and prevented or extinguished all dissent and all independence of thought and expression."12 The Latin American delegates and several developing countries noted that the human rights situation in Cuba could not be considered in isolation from the attempts to destabilize the Cuban government; they noted the outstanding record of Cuba on economic, social, and cultural rights. The Indian representative said, "My country does not believe that any consideration of the situation of human rights . . . in any society should be invoked for the purposes of forcing changes in the socio-economic system freely adopted by a society." ${ }^{13}$ Several countries on both sides commended the cooperation of the government of Cuba.

Outside of the public discussion, tense negotiations continued between representatives of the European Community, on the one hand, and the Latin American "Group of 8 ," on the other. ${ }^{14}$ The principal basis of the negotiation was a text prepared by both sides upon which agreement could be achieved on all points except on what, if any, follow-up mechanism to give the report on Cuba. Pursuant to the text the Commission would have thanked the Cuban government for its cooperation and for the "reaffirmation of the desire of the Cuban authorities to continue co-operation in the human rights sphere and to keep the Secretary-General informed . ... ${ }^{\prime 15}$ The Latin American group, however, sought a text which did not keep Cuba on the agenda of the Commission, maintain the existence of the group, or meet any of the other objectives of the United States. Instead, the Latin American draft essentially terminated consideration by the Commission of the issue. The European Community negotiators sought some follow-up related to the report on Cuba. There was an agreement in the negotiations, in any case, that neither side would submit their proposals as resolutions or take any other action, until all hope of consensus was exhausted.

On 3 March 1989 the US delegation violated this agreement by submitting their draft resolution to the Secretary of the Commission while the negotiations were still in process. ${ }^{16}$ The United States later apologized, saying

11. U.N. Doc. E/CN.4/1989/SR.42, at 6 (1989).

12. Id. at 8 .

13. K. Sharma, Permanent Representative of India, Statement to UN Commission on Human Rights, 28 Feb. 1989, at 2.

14. The European Community efforts were ratified by the Western European and Other Group, including the United States. The Latin American "Group of 8 " negotiated on behalf of Cuba.

15. The text was later issued as U.N. Doc. E/CN.4/1989/L.90 (1989).

16. The US resolution was submitted on behalf of Canada, the Netherlands, and the United Kingdom as cosponsors. 
that the submission had been made by an overzealous junior member of the delegation. The negotiations were beginning to reach an impasse, but had not been ended. The submission of the US draft resolution on Cuba, which was later issued as L.89, ${ }^{17}$ gave that draft priority in being considered first under the Commission's rules. The Latin American resolution was submitted by Colombia, Mexico, Panama, and Peru half an hour later and was designated as L.90. ${ }^{18}$

The US preemptory submission of its resolution was considered such a breach of honor among the negotiators that Michael Lillis (Ireland) and Mercedes Rico (Spain) withdrew from the discussions and refused to continue as negotiators; valuable days were lost in getting the negotiations restarted. Another consequence of the US blunder was that the British and the Dutch withdrew their cosponsorship of L.89, until the United States apologized to the Western European and Other Group. Lillis and Rico, in turn, apologized to the Latin American "Group of 8." By the time the resolution should have been considered by the Commission, however, the negotiations had recommenced with the British, Canadian, and Dutch representatives negotiating for the cosponsors of L.89-but not for the European Community or the Western European and Other group. Negotiations proceeded with the Commission continuing its voting on other resolutions and then periodically adjourning the public deliberations in the hope that the negotiators would succeed in obtaining a resolution which would achieve a consensus. A consensus resolution would have far greater authority than a resolution adopted by a vote. Also, delegations were reluctant to be forced to vote and thus incur the wrath of the other side of the dispute.

Finally, at a few minutes before 11:00 p.m. on Thursday, 9 March 1989, the negotiators entered the Commission's room and called for the Commission to come into public session. ${ }^{19}$ Neither the chair of the Commission nor most delegations were apparently informed as to what would happen next. The head of the United Kingdom delegation first asked the Commission to consider resolution L.90 (the Latin American draft) before the US resolution in L.89 (which had by then been cosponsored in revised form by Canada, Morocco, the Netherlands, and the United Kingdom). ${ }^{20}$ That request was accepted by the Commission without a vote.

The Latin draft resolution in L.90 was then amended orally by its sponsors to state that the UN Secretary-General would continue to maintain direct contacts with the government of Cuba. The UK ambassador sought the floor once again to introduce a proposal for an additional amendment to L.90

17. U.N. Doc. E/CN.4/1989/L.89 (1989).

18. U.N. Doc. E/CN.4/1989/L.90 (1989).

19. The negotiators had evidently been informed that the interpreters had only been hired until $11: 00$ p.m. that night.

20. U.N. Doc. E/CN.4/1989/L.89/Rev.1 (1989). 
which added two concepts: first, that the Secretary-General would maintain contact not only with the government, but also with the "people of Cuba"; and second, the Secretary-General would report to the Commission "as appropriate." ${ }^{21}$ The UK ambassador explained that these two elements were the only remaining issues of dispute between the negotiators, but that no agreement could be achieved.

The proposed UK amendment to L.90, which would have strengthened it slightly and would have kept Cuba on the agenda of the Commission for 1990, was then put to a vote. The vote was far closer than anyone had anticipated: seventeen in favor, seventeen against, and eight abstentions. Thus, the proposed UK amendment failed by the narrowest of margins. (Later, several delegates noted that the vote of Botswana against the British amendment was a surprise. Other votes of interest included the abstentions of Argentina, Brazil, Rwanda, Swaziland, and Venezuela. Colombia, Cyprus, and Sri Lanka voted against the UK resolution. $)^{22}$ The chair called for a vote on draft resolution L.90 as amended only by the Latin cosponsors and not by the British proposal. At that point it appeared that the UK negotiators and the United States had not anticipated losing the vote on the British amendment. The UK and the US could have saved face and agreed to accept the remaining resolution by consensus. Such a consensus resolution would have had considerable authority and left both sides with some ability to claim success.

Instead, the United Kingdom and the United States let resolution L.90 go to a vote. They did not even coordinate their forces by explaining to their allies how they would vote on L.90. The result was an embarrassing disarray. The roll call vote began with Morocco, ${ }^{23}$ which had cosponsored L.89 (the US resolution) and had voted in favor of the British amendment to L.90. They reasoned, without guidance from the United States or the United Kingdom, that $L .90$ would be unacceptable without the proposed British amendment. So, Morocco voted against L.90. Portugal and Spain, which had also voted for the British amendment, abstained. The United Kingdom and the United States, wishing belatedly to save face and to join the weak resolution on Cuba, voted in favor of L.90. ${ }^{24}$ After the United States and United Kingdom

21. E/CN.4/1989/SR.56/Add.1, at 2 (1989).

22. The following delegations voted in favor of the proposed UK amendment: Bangladesh, Belgium, Canada, France, Gambia, Federal Republic of Germany, Italy, Japan, Morocco, Philippines, Portugal, Senegal, Somalia, Sweden, Togo, United Kingdom, and United States. The following delegations voted against the proposed UK amendment: Botswana, Bulgaria, China, Colombia, Cuba, Cyprus, Ethiopia, German Democratic Republic, India, Iraq, Mexico, Panama, Peru, Sri Lanka, Ukrainian SSR, USSR, and Yugoslavia. Abstaining were: Argentina, Brazil, Nigeria, Pakistan, Rwanda, Spain, Swaziland, and Venezuela. Sao Tome and Principe did not participate in the vote.

23. Votes at the Commission begin with a country chosen at random by the Secretary. In this case, the secretary chose Morocco.

24. The UK vote in favor of the resolution was greeted by audible laughter in the room. 
indicated their position, most of the other Western countries voted in favor of their solution. In the end, L.90 was adopted by a vote of thirty-two in favor, one (Morocco) against, and ten abstaining. Then the UK head of delegation stated that he wished to seek a vote on the US resolution in L.89. In view of the failure to obtain a majority even on the very modest British amendment to L.90, it was very difficult to understand why the UK head of delegation would pursue a vote on the far more ambitious resolution in L.89. The draft resolution in $L .89$ would continue the existence of the group which had visited Cuba, continue its monitoring of the human rights situation in Cuba, encourage a second visit, and would call for a discussion of Cuba under agenda item 12. It was even harder to understand why the US delegation, which was sitting right next to the UK delegation, did not suggest that L.89 be withdrawn. Instead, the vote was taken and the draft resolution in L.89 lost badly on a procedural motion by the Cuban delegation to take no action: sixteen in favor of taking no action; seven against the motion; and nineteen abstaining. The US-UK position was not even supported by Belgium, France, Italy, Japan, Portugal, or Sweden, which had generally supported the US-UK efforts up to that point. ${ }^{25}$ Several of those delegates and even such countries as Bangladesh and Gambia (which had voted with the United States on every issue) complained after the session that they had been told that L.89 would never be brought to a vote; that they had not been advised adequately of the tactics to be followed; and that they could not understand why L.89 had been brought to a vote. Neither the US nor the UK delegates could explain why they pursued a series of votes which demonstrated deepening disarray and ultimately made the US position look like an abject failure, when in fact, the Commission was quite evenly divided on the critical vote.

\section{El Salvador}

The special representative on El Salvador, Pastor Ridruejo of Spain, reported that the situation of human rights in that country had seriously deteriorated. In particular, he noted, "An alarming number of politically motivated summary executions, including mass executions, have been carried out by members of the State apparatus, particularly members of the armed forces ..."

25. It may have been that the United Kingdom and the United States expected the Western European and Other (WEO) group to unite in opposing the Cuban motion because the WEO group had established a firm position of principle to oppose no-action motions under Commission rule 65(2) which may prevent the Commission from considering human rights situations on their merits. The Cuban motion, however, was introduced under Commission rule 65(1) that permits the Commission to avoid a second vote on a subject once a resolution has been adopted on the same issue. The WEO group had themselves used rule 65(2) motions in other circumstances and had no fixed view opposing such motions. 
and that this number had increased over that of recent years. ${ }^{26}$ Nevertheless, the resolution on El Salvador, written by Colombia, Mexico, and Peru but negotiated with the government of El Salvador, was considerably weaker than in previous years, failing to mention, for instance, the "death squads" who, according to the special representative, had "increased their criminal activities $^{\prime 27}$ in the past year.

\section{Guatemala}

Hector Gros Espiell (Uruguay), the expert appointed in 1987 under the Advisory Services program, pointed in his report to serious human rights violations in Guatemala. Once again, however, he seemed to treat the government as a victim of circumstance: "these [violations] are the outcome not of government orders or policy but of factors, of acts committed by power circles and a persistent climate of violence that are still beyond effective government control. . . ${ }^{\prime 28} \mathrm{He}$ thus failed to identify the major cause of the continuing violations, that is, the government's "dirty war" counter-insurgency policy which is in the hands of the military and not the civilian authorities. Guatemalan opposition groups pointed out that the expert's evaluation of the situation was more positive than those of the Inter-American Commission on Human Rights, independent human rights monitors, and the Commission's own reports on disappearances and executions.

Several Commission participants, including the Swedish delegation, still believe that the decision in 1987 to remove Guatemala from agenda item twelve (violations) and place it under agenda item twenty-two (advisory services) was "premature." The weak Commission resolution in 1989 "recognized," however, the government's commitment to human rights while expressing the Commission's concern "at the harmful conditions that still exist. ${ }^{29}$

\section{Haiti}

The excellent report by the expert appointed under the Advisory Services program, Philippe Texier of France, concluded that under the new government of General Prosper Avril, "the political will to take specific measures aimed at ensuring everyday observance of [human] rights has not so far been

26. U.N. Doc. E/CN.4/1989/23, at 26 (1989).

27. Id.

28. U.N. Doc. E/CN.4/1989/39, at 19 (1989).

29. C.H.R. Res. 1989/74, U.N. Doc. E/CN.4/1989/L.11/Add.8, at 38, 39 (1989). 
convincingly demonstrated. . . . ${ }^{\prime 30}$ Consequently, he wondered "whether minimum standards of respect for international norms should not be required in order for a country to benefit from United Nations advisory services, ${ }^{\prime \prime 31}$ and asked the Commission to consider the possibility of appointing a Special Rapporteur. If Advisory Services were to be continued, he recommended that the program's focus should be on organizing elections and promoting an independent judiciary, and that local human rights groups be associated with the program. The French delegation promoted and the Commission adopted a resolution to continue the mandate of the expert, adopting his suggestions and also requesting him "to provide information ... on the development of the human rights situation in Haiti. ${ }^{\prime 32}$

\section{Iran}

In addition to the Report of the Special Rapporteur on Executions (see infra at note 41), the Commission had before it the report of Special Rapporteur Galindo Pohl (El Salvador) and a memorandum of Amnesty International recording over 1,000 names of political prisoners reportedly killed in a "wave of executions of political prisoners." ${ }^{\prime 3}$ Since July 1988, Mr. Pohl, who is still denied access to the country, recorded reliable reports of arbitrary arrests, ill-treatment of political prisoners, torture, and unfair trials. A Western-sponsored resolution, which was adopted twenty in favor, six against, with twelve abstentions, urged Iran to grant access to the special rapporteur and expressed deep concern over the wave of executions as well as the numerous and detailed allegations of other human rights violations.

As has been the practice for the last couple of years, no delegation introduced the resolution against Iran because of concern that that government or its citizens might be singled out for retaliation. The vote against Iran was much stronger than at the Commission in 1988 or in the General Assembly in 1988, apparently because of the death threats against Salman Rushdie. While at the General Assembly, there had been efforts to negotiate with the Iranian government for a moderate resolution in exchange for assurances by Iran of cooperation with the special rapporteur. The Rushdie affair ended, at least for the 1989 session, any efforts at negotiation with the Iranian delegation.

\section{Iraq}

The Commission's most dismal failure was its refusal to take action on Iraq which, according to Amnesty International, "clearly and incontrovertibly

30. U.N. Doc. E/CN.4/1989/40, at 20 (1989).

31. Id. at 22.

32. C.H.R. Res. 1989/73, U.N. Doc. E/CN.4/1989/L.11/Add.8, at 35, 37 (1989).

33. U.N. Doc. E/CN.4/7989/26, at 8 (1989). 
presents a situation of the most flagrant and massive violations of human rights. ${ }^{34}$ With the Special Rapporteur on Executions recording thousands of alleged deaths by chemical weapons and mass executions and the Working Group on Disappearances listing over 2,600 unresolved cases and reports of routine torture even against the children of political opponents, both the International Commission of Jurists and Amnesty International said in their oral interventions that the "credibility of the Commission" depended on its taking action against Iraq. ${ }^{35}$ After consideration of Iraq was discontinued under the confidential 1503 procedure, the twelve European Community countries (minus France), Australia, Canada, and Sweden tabled a resolution to appoint a Special Rapporteur. Only Japan, Peru, and Togo joined the Western countries in opposing a motion by Iraq (17-13-9) to take no action on the draft. The successful plurality included the six Moslem and Arab countries as well as Botswana, Brazil (a principal source of arms to lraq), China (which also sells missiles to Iraq), Cuba, Cyprus, Ethiopia, India, the Philippines, Sao Tome, Sri Lanka, and Yugoslavia.

\section{Israeli-Occupied Territories}

The Commission reaffirmed the inalienable right of the Palestinian people to self-determination and the establishment of an independent sovereign state on their national soil, welcomed the declaration of the state of Palestine, and considered the decisions of the Palestine National Council of 15 November 1988 a prerequisite for the establishment of a just and lasting peace in the Middle East.

\section{Southern Lebanon}

The Commission, by thirty in favor, one (United States) against, and twelve (mostly Western European countries) abstaining, strongly condemned Israel for its continued violations of human rights in southern Lebanon and called upon Israel to put an immediate end to such practices, to liberate Lebanese prisoners, to return all those expelled to their homes, to stop expelling Palestinians arbitrarily to southern Lebanon, and to implement the resolutions of the Security Council which require the immediate, and unconditional withdrawal of Israel from all Lebanese territory.

34. Amnesty International, Evasion of Covernment Accountability 3 (oral intervention before 35. Id. UN Comm'n on Human Rights, Mar. 1989). 


\section{Romania}

For the first time in five years, the Commission on Human Rights in 1989 recommended to the Economic and Social Council that a new Special Rapporteur be appointed on a country situation. The human rights situation has been deteriorating in Romania. At the 1989 session, the proposed rural "systematization," the treatment of the Hungarian and German minorities, and the declining enjoyment of economic, social, and cultural rights were the subject of numerous governmental and NGO interventions. A Swedish resolution to appoint a Special Rapporteur to study the human rights situation in Romania received an enormous boost when the deputy foreign minister of Hungary came to the Commission to announce his country's cosponsorship for the measure. This gesture prevented the issue from becoming an East-West matter and made passage of the resolution likely. Two days before the vote, and reportedly at the insistence of the Soviet Union, Romania informally offered to invite the Commission's Bureau to visit Romania. When the cosponsors of the resolution insisted that the offer be made in writing and contain at least the guarantees provided to the mission which visited Cuba, however, the Romanians withdrew their offer. With the countries of Eastern Europe not participating in the vote, the Swedish resolution passed easily, twenty-one in favor, seven against, and ten abstentions. The Romanian delegate responded that his country considered the vote "null and void" and made it understood that the Special Rapporteur was not likely to be permitted into his country. ${ }^{36}$

The Commission also adopted a resolution by a vote of twenty-six in favor, five against, and twelve abstentions, calling for an advisory opinion by the International Court of Justice about applicability of the UN Convention on Privileges and Immunities to the detention by the Romanian government of a Romanian citizen, Dumitru Mazilu, who had been prevented from completing his work as an expert on youth matters for the UN Sub-Commission on Prevention of Discrimination and Protection of Minorities.

\section{South Africa (and Namibia)}

The Commission heard the report of the "Group of Three"37 created within the framework of the International Convention on the Suppression and Punishment of the Crime of Apartheid and the report of the ad hoc Working Group of Experts on South Africa. This latter report is essentially based on

36. U.N. Doc. E/CN.4/1989/SR.56, at 5 (1989).

37. U.N. Docs. E/CN.4/1989/31 \& 33 (1988) (The members of the Group of Three were from Ethiopia, the German Democratic Republic, and Mexico.). 
first hand information which the experts collected, in cooperation with the Special Rapporteur on Summary and Arbitrary Executions, in Europe and in front-line states. For twenty years, access to South Africa has been continually refused to the ad hoc Working Group. The Commission again adopted resolutions demanding that South Africa abolish the system of apartheid in all its forms, reaffirming the inalienable right of the people of South Africa and Namibia to self-determination and independence, and condemning the continuing collaboration of certain Western states which obstruct efforts to eliminate apartheid. The Commission called once again upon all governments to take measures at a national level with a view to putting a stop to their commercial activities in the territory of South Africa as well as of Namibia.

\section{THE ECOSOC RESOLUTION 1503 PROCEDURE}

Under the confidential procedure established pursuant to ECOSOC resolution 1503, the Commission continued consideration of the cases of Brunei, Haiti, Paraguay, and Somalia while discontinuing consideration of Honduras, Iraq, Syria, and Zaire (though Zaire will apparently be discussed in a special closed session next year). The viability of this procedure is increasingly being questioned. First, it is unclear what positive effect "confidential" actions have (particularly when compared with the public resolutions which were not an alternative when 1503 was instituted). Second, delegations appear even less likely to criticize their counterparts in confidential voting than when those votes are publicly, recorded. Hence, while the confidential voting on Iraq was reported to be twenty-four in favor, twelve against, and seven abstentions in that government's favor, the no-action motion on the public resolution was passed by only seventeen in favor, thirteen against, and nine abstentions. $^{38}$

\section{THEME PROCEDURES}

Since 1980 the UN Commission on Human Rights has been slowly developing an approach to human rights violations which focuses on the kind of abuse and not solely on countries where serious problems arise. Accordingly, the Commission established the Working Group on Enforced or Involuntary Disappearances in 1980, the Special Rapporteur on Summary or Arbitrary Executions in 1982, the Special Rapporteur on Torture in 1985, and the

38. Part of this change may have been due to increased lobbying which occurred after the initial 1503 vote and before the public vote on Iraq. 
Special Rapporteur on Religious Intolerance in 1986. Each of these mechanisms has the authority to receive information on human rights problems within its area of concern and to take "effective action" in trying to urge governments to resolve the problems. In 1987 the Commission also established a Special Rapporteur on Mercenaries, who is authorized to visit countries where mercenaries have committed abuses, but who has not yet been given authority to take "effective action." Nevertheless, in 1988 the Commission characterized the Special Rapporteur on Mercenaries as a theme procedure and extended its mandate for two years at the same time as it extended the mandate of other theme mechanisms. Together, the theme procedures do the most important concrete work of the Commission in protecting human rights in specific cases by saving lives, stopping torture, resolving disappearances, etc. Nevertheless, the theme procedures are still evolving and being improved.

The decision of the Commission in 1988 to extend the mandate of all the theme procedures for two years constituted a significant step in solidifying support for and giving a measure of independence to the Working Group on Enforced or Involuntary Disappearances as well as the theme rapporteurs. The 1988 decision meant that none of the theme procedures needed to be extended at the 1989 Commission session. Nevertheless, the USSR delegation proposed a resolution which expressed appreciation to the special rapporteurs and other monitoring mechanisms of the Commission for their contribution in implementing universally recognized standards of human rights. The initial USSR proposal was for a study of how the various thematic and country rapporteurs do their work. The Western European delegates were concerned that such a study might lead to limitations on the work of the rapporteurs. It is precisely the individual initiative and independence of the rapporteurs which make them effective in protecting human rights. Also, their procedures are still evolving and there was concern that any study might eventually lead to the rapporteurs being given only the lowest common denominator of authority without the capacity of creativity in pursuing their quite distinct mandates. After some negotiation, the initial Soviet proposal for a study was modified to request the UN Secretary-General to consider also convening a meeting of the Commission special rapporteurs, the chair of the Commission, the chair of the Sub-Commission, and the five rapporteurs representing the Sub-Commission. The resolution, which was introduced by an Austrian representative to the Commission, was adopted by consensus.

While the Commission generally expressed satisfaction with the work of the present theme rapporteurs, the British delegation was unable to convince the Commission to establish a new special rapporteur to examine the question of persons deprived of their liberty for seeking to exercise peacefully their rights to freedom of expression, association, and assembly. The proposal was blocked by India and several other third world delegations. In the end, the British delegation had to settle for a resolution, similar to last year's, calling on governments to release political prisoners. 
In a salient 1988 intervention, Amnesty International suggested that the theme mechanisms provide an objective vehicle by which the Commission can identify situations of serious human rights violations and find ways of according them particular attention. It often seems, however, as if the Commission lacks the political will to respond appropriately to the information provided by the rapporteurs. Hence, despite clear signs from the Special Rapporteur on Summary or Arbitrary Executions and the Working Group on Enforced or Involuntary Disappearances concerning the gravity of the situation in Iraq, the Commission failed to act. Similarly, although the Working Group on Disappearances reported after visiting Colombia that in most cases "circumstantial evidence strongly suggests or precise information clearly demonstrates involvement of units of the armed forces or security services in enforced or involuntary disappearances, ${ }^{\prime 39}$ no resolution on that country was even introduced. Indeed, the resolution on the Working Group, which is ordinarily introduced by the French delegation to the Commission, did not even refer to the group's visit to Colombia.

\section{WORKING GROUP ON ENFORCED OR INVOLUNTARY DISAPPEARANCES}

In its best report yet, the Working Group on Enforced or Involuntary Disappearances reported transmitting 392 cases alleged to have taken place in 1988 in fifteen countries. The largest number of outstanding cases are found in Argentina (3,387, all from before 1983), Guatemala $(2,851)$, Iraq $(2,728)$, and El Salvador $(2,141)$. The group expressed its "concern over the total lack of cooperation from . . . Governments which have never provided substantive replies to the allegations transmitted to them, such as Afghanistan, Angola, Chile, Guinea, the Islamic Republic of Iran, Nepal and Seychelles."40 It announced that at its first 1989 session it would examine the various initiatives aimed at preparation of international declarations or conventions on the subject. The group again noted the inadequacy of the institutional and legal framework in most affected countries, in particular limitations on habeas corpus.

The Working Group emphasized the importance of the judgment of the Inter-American Court of Human Rights finding Honduras liable for disappearances ${ }^{41}$ as "a precedent for the investigation and judgement of an enforced disappearance by a supranational judicial organ." ${ }^{42}$ It highlighted two aspects of the Court's holding which supported Working Group practice:

39. U.N. Doc. E/CN.4/1989/18/Add.1, at 33 (1989).

40. U.N. Doc. E/CN.4/1989/18, at 85 (1989).

41. Angel Manfredo Velasquez Rodriquez v. Honduras, Inter-American Court of Human Rights, 19 Jul. 1988.

42. U.N. Doc. E/CN.4/1989/18, at 6 (1989). 
(1) responsibility for violations of human rights continues irrespective of changes in government and (2) states are obliged to investigate disappearances as long as uncertainty remains, with no time limit. The Dutch delegation (whose member, Toine van Dongen is also on the Working Group) would later emphasize these points to "put to rest" the argument of "some governments" (i.e., Argentina) that they cannot be held responsible for disappearances dating back to earlier administrations. Portugal also stressed these points.

The group drew the attention of the governments of El Salvador, Iran, Iraq, the Philippines, and Sri Lanka to the recommendation of the General Assembly and the Commission that governments concerned with disappearances consider inviting the Working Group to visit their country.

\section{SPECIAL RAPPORTEUR ON TORTURE}

In his fourth annual report, the Special Rapporteur on Torture, Professor Peter Kooijmans (Netherlands) concluded that "torture is still rampant in various parts of the world, ${ }^{\prime 43}$ most often accompanying civil strife and civil war. During the year, he accepted invitations for consultative visits to South Korea, Peru, and Turkey and in each case made evaluations and recommendations which are included in his report. During the year he transmitted allegations to thirty-seven countries for clarification and sent forty-two urgent appeals for immediate government attention. Some twenty states did not reply in any form. All in all, the fourth report was a considerable improvement over the third report in providing more detail about the information received by the Special Rapporteur and what he did in response.

Among his recommendations, the Special Rapporteur suggested that a legal provision prescribing that a person be given access to a lawyer not later than twenty-four hours after his arrest usually constitutes an effective protection against torture, so long as governments actually comply with such a provision. He also recommended that the right of habeas corpus should be strictly respected and never suspended.

\section{SPECIAL RAPPORTEUR ON SUMMARY OR ARBITRARY EXECUTIONS}

In his seventh report to the Commission, the Special Rapporteur on Summary or Arbitrary Executions, Amos Wako (Kenya), reported addressing urgent cables to twenty-three governments (of whom only eight responded) and

43. U.N. Doc. E/CN.4/1989/15, at 15 (1989). 
letters concerning alleged executions to thirty-six governments (of whom only fifteen responded).

Mr. Wako's report provided detailed summaries of the situations giving rise to his concerns. Among the country situations, the special rapporteur referred to "persistent reports received that several thousand persons had been executed without trial or with a trial of a summary nature ${ }^{\prime 44}$ in Iran and reports that several thousand civilians were killed in a series of attacks using chemical weapons in Iraq. In this respect, he concluded that "in some areas where peace negotiations have ended international armed conflicts, reports are emerging which indicate that the governmental instruments of power have turned from the enemy across the border to civilians within the country, with the result that there has been a very noticeable increase in summary or arbitrary executions by the governments concerned of their own civilians." ${ }^{\prime \prime 5}$

The rapporteur also noted with concern increased reports of the use of chemical weapons as well as increased allegations of killings by law enforcement officials during demonstrations.

The special rapporteur suggested that the effective implementation of his mandate would be enhanced through more on-site visits and through the creation of a team of forensic medical experts to accompany and assist him on the visits.

\section{SPECIAL RAPPORTEUR ON RELIGIOUS INTOLERANCE}

The Commission received the report of its special rapporteur on religious intolerance, Angelo Vidal D'Almeida Ribeiro (Portugal), whose report followed the same approach as the other rapporteurs. The Commission has been considering for several years the possibility of drafting a Convention on the Elimination of All Forms of Intolerance and of Discrimination Based on Religion or Belief. Many delegates who recall the twenty years it took to draft a declaration on this subject are uncertain whether the expense and effort to draft a treaty would be worthwhile, and similarly wonder whether a treaty would actually improve relevant standards. Others want to follow the normal progression in standard-setting from a declaration to a convention. At its 1989 session the Commission once again temporized on their decision as to this controversial issue.

\section{SPECIAL RAPPORTEUR ON MERCENARIES}

In the second year of his mandate, the special rapporteur on mercenaries, Enrique Bernales Ballesteros of Peru, responded to invitations from Angola

44. U.N. Doc. E/CN.4/1989/25, at 28 (1989).

45. Id. at 62 . 
and Nicaragua to examine reports of mercenary aggression against those countries. The report on his mission to Angola was presented to the General Assembly while a report covering his visit to Nicaragua was prepared for the Commission. The report analyzes the US-sponsored "contra" war against Nicaragua in light of the judgment of the International Court of Justice holding that the aggression violates customary international law. After finding (as had the World Court) that numerous non-Nicaraguans, including US citizens, Cuban-Americans, and others, were involved in mercenary acts against Nicaragua, the special rapporteur turned carefully to the Nicaraguan government's categorization of all the Contras, including Nicaraguan citizens, as mercenaries. He noted that, in accordance with Additional Protocol I of the Geneva Conventions, one of the prerequisites for mercenary status is that the person concerned should be a foreigner. Nevertheless, he stated that it would be "in the interests of the international community that it should consider from a legal standpoint the situation by which nationals of a country are recruited, armed, financed, equipped and used by a third country for aggression against their own country, on an individual basis or as part of a group serving the interests of the country that recruits and employs them directly or indirectly. ${ }^{146}$

\section{CONVENTION ON THE RIGHTS OF THE CHILD}

Since 1981, an open-ended Working Group has met prior to the Commission's session to draft a Convention on the Rights of the Child. The Working Group held its session from 28 November to 8 December 1988 and adopted the text of the draft Convention on second reading for transmission to the Commission; accordingly, the Commission had before it both the text of the draft Convention and the report of the Working Group.

The question of military recruitment of youths had been a difficult one for the Working Group. The problem was to avoid falling below existing standards of humanitarian law, on the one hand, while trying to adopt a text by consensus, on the other. During the Commission debate, some delegations expressed concern that the present draft does not ban recruitment under eighteen, but only provides that "States Parties shall take all feasible measures to ensure that persons who have not attained the age of 15 years do not take a direct part in hostilities, ${ }^{\prime \prime 7}$ thus failing to extend to children the level of protection equal to that recognized in Protocol II of the 1977 Geneva Convention. Other delegations lamented that the right of the child to choose

46. U.N. Doc. E/CN.4/1989/14, at 44-45 (1989).

47. U.N. Doc. E/CN.4/1989/29, at 16 (1989) (Draft Convention on the Rights of the Child, art. 38(2)). 
his or her own religion was removed from the draft text. Some delegations from North Africa warned that this Convention may have negative effects, because it does not take enough consideration of the family.

The expression of these concerns did not prevent the Commission from deciding without a vote to adopt the draft Convention and to transmit it, as well as the report of the Working Group, to the General Assembly-through the ECOSOC-for consideration, with a view to the adoption of the Convention by the Assembly at its forty-fourth session in 1989. NGOs concerned with children's rights hope that, in the meantime, efforts will be made to ensure a more satisfactory text.

\section{SUB-COMMISSION ON PREVENTION OF DISCRIMINATION AND PROTECTION OF MINORITIES}

While in past sessions the Commission on Human Rights had expressed dissatisfaction with the work of its Sub-Commission on Prevention of Discrimination and Protection of Minorities, the debate at the 1989 session of the Commission reflected the success of the August-September 1988 session of the Sub-Commission. The Sub-Commission produced new initiatives on the death penalty, mental patients, computerized personal files, the independence of judges and lawyers, and the rights of indigenous peoples. The Soviet delegation pointed out that thirty-five of the forty resolutions adopted by the Sub-Commission were accepted by consensus. Few interventions, however, failed to raise the question of the Romanian expert Dumitru Mazilu, who is apparently being prevented by his government from coming to Geneva. Many also believe that the Sub-Commission devotes too much time to issues already being considered by the Commission and other UN organs. A joint NGO intervention welcomed the success of the Sub-Commission and suggested that even more could be achieved through the increased use of working groups at the Sub-Commission. The intervention also warned that the question of independence goes deeper than the Mazilu case, pointing out that nine Sub-Commission experts were government foreign service officers subject to intense pressure, particularly when voting on country situations. This sentiment was strongly echoed by the delegates from Ireland and the Netherlands.

In other actions relating to the Sub-Commission, the Commission:

-recommended that the General Assembly consider the adoption and publication of the "guidelines on the use of computerized personal files $^{\prime \prime 48}$ prepared by the Sub-Commission expert Louis Joinet (France),

48. C.H.R. Res. 1989/43, U.N. Doc. E/CN.4/1989/L.11/Add. 6, at 57 (1989). 
-recommended to ECOSOC that it authorize an open-ended Working Group to meet for two weeks before the Commission's next session to "examine, revise and simplify as necessary" 49 the draft body of principles and guarantees received from the Sub-Commission for the protection of persons detained on grounds of mental ill-health or suffering from mental disorder,

- referred the Sub-Commission's draft declaration on the independence of judges and lawyers to the UN Crime Branch where the Basic Principles on the Independence of the Judiciary were drafted and where Basic Principles on the Role of Lawyers are being prepared,

- confirmed the appointment of Miguel Alfonso Martinez (Cuba) as special rapporteur of the Sub-Commission to carry out a study on treaties between indigenous peoples and governments.

\section{SECOND OPTIONAL PROTOCOL ON THE DEATH PENALTY}

One of the most impressive successes of the Sub-Commission was the Commission's prompt acceptance of the Sub-Commission's draft Second Optional Protocol to the International Covenant on Civil and Political Rights for the abolition of the death penalty. The 1989 Commission recommended to the General Assembly, through ECOSOC, the adoption of the Second Optional Protocol. Although a number of the Commission members still maintain the death penalty, they were apparently convinced that the Optional Protocol would, indeed, be optional. That is, the governments that no longer have the death penalty, such as Canada, France, the Federal Republic of Germany, Spain, Sweden, and the United Kingdom, wanted the Optional Protocol, so as to reaffirm internationally their decision to abolish capital punishment. Governments which still have the death penalty did not block the adoption by consensus of the resolution recommending the Second Optional Protocol. The success of the draft Second Optional Protocol was due in part to respect for Marc Bossuyt, chair of the 1989 Commission, who had drafted the Second Optional Protocol when he was previously a member of the Sub-Commission.

\section{CONSCIENTIOUS OBJECTION TO MILITARY SERVICE}

In 1987 the Commission on Human Rights adopted, by a vote of twentysix in favor, two (Iraq and Mozambique) against, and fourteen abstaining, a resolution which contained language garbled by negotiations apparently recognizing conscientious objection to military service as a human right. At

49. C.H.R. Res. 1989/40, U.N. Doc. E/CN.4/1989/L.11, Add.6, at 54 (1989). 
its 1989 session the Commission reaffirmed by consensus in much clearer language "the right of everyone to have conscientious objections to military service as a legitimate exercise of the right of freedom of thought, conscience and religion." ${ }^{150}$ The 1989 resolution on conscientious objection was cosponsored for the first time by Hungary, but after the adoption of the resolution several countries (China, Cuba, Ethiopia, Mexico, the USSR, and Yugoslavia) expressed reservations which would have led them to have abstained if there had been a vote, and Iraq said they would have voted against the resolution. Nevertheless, none of their reservations were so strong as to require them to block the Commission's consensus.

\section{ADVISORY SERVICES}

The Commission on Human Rights, in a resolution adopted by consensus, commended the progress which has been made by the Centre for Human Rights in providing practical assistance to governments in fulfilling their human rights obligations by developing human rights institutions, giving training courses, drafting legal texts in conformity with international standards, coordinating national technical assistance programs, asking other UN bodies to recommend advisory services to achieve the rights within their particular domain, and pursuing other specific projects. The Commission also encouraged more contributions to the UN Voluntary Fund for Advisory Services and Technical Assistance in the Field of Human Rights to make these projects possible.

Nevertheless, the blossoming advisory services program was subjected to criticism by Western governments and a coalition of NGOs for not using concrete criteria in the determination of programs and countries on which to focus. Several speakers also warned that the advisory services program should not be used to replace or undermine the reporting, monitoring, and investigating activities of the Commission.

\section{ECONOMIC, SOCIAL, AND CULTURAL RIGHTS}

Once again, the debate on economic, social, and cultural rights was marked by a strong difference of views between the developing and socialist countries, on the one hand, and the Western states on the other. The Commission heard the report of the Working Group of Governmental Experts on the Right

50. C.H.R. Res. 1989/59, U.N. Doc. E/CN.4/1989/L.11/Add.8, at 5 (1989); see Weissbrodt, The United Nations Commission on Human Rights Confirms Conscientious Objection to Military Service as a Human Right, 35 Netherlands International Law Review 53, 65-66 (1 Nov. 1988). 
to Development which recommended that the coordination of activities of UN organs concerning development should be reinforced; that a global consultation on the realization of the right to development should be organized; and that means of evaluation should be established to measure the progress achieved in the reinforcement and implementation of the Declaration on the Right to Development.

Resolutions were adopted without a vote on the right to development, human rights and extreme poverty, and non-discrimination in the field of health; other resolutions, such as the one on the realization of economic, social, and cultural rights, were adopted over the opposition of the Western countries (except for the abstention of Portugal).

Over stiff Western opposition, the Commission approved (30-6-6) a Latin American proposal to include, as a specific point on its agenda next year, economic adjustment policies, the debt burden and its effects on the full enjoyment of human rights and, in particular, on the implementation of the Declaration on the Right to Development. According to Peruvian diplomat Manuel Rodriguez, "until now, the Commission has only studied violations of civil and political rights on the part of underdeveloped countries. Now we will be able to study the role of the industrialized countries in economic adjustment policies which prevent the fulfillment of these rights. ${ }^{151}$

\section{OTHER ISSUES}

The Commission also adopted resolutions on administrative detention without charge or trial; detention of UN personnel; a framework for future efforts on periodic and genuine elections; hostage-taking; independence of the judiciary, jurors, and assessors and the independence of lawyers; the right of everyone to leave their country and return; human rights and mass exoduses; migrant workers; continuation of the drafting of a declaration on the rights of minorities; continuation of the drafting of a declaration on the rights of human rights defenders; national institutions for the protection of human rights; a renewed call for contributions to the Voluntary Fund for Victims of Torture; and the mounting of a World Public Information Campaign for Human Rights.

\section{CONCLUSION}

The 45th session of the UN Commission on Human Rights took a number of incremental steps towards improving the protection of human rights

51. This statement was made to media representatives and other observers at the Commission, but not in the official debate. Cf. U.N. Doc. E/CN.4/1989/SR.47, at 4 (1989). 
throughout the world. The session was marked by a relatively slow beginning as a larger number of delegates than usual-particularly in the influential Western European group - were attending their first Commission. The delays at the beginning resulted in many late-night meetings at the end of the sixweek session. Nevertheless, by the end the Commission was able to make most of its decisions by consensus.

A new factor in the examination of country situations was the decision of Bulgaria, the German Democratic Republic, the Ukrainian SSR, and the USSR not to participate in voting on resolutions concerning Albania, Iraq, Iran, and Romania-giving those resolutions a greater chance of passage. Except for the issue of Cuba, the Commission was marked by a slight decrease in ideological polarization as compared with previous sessions. Even resolutions on Albania, Burma, and Romania were not generally perceived in ideological terms. This decrease in ideological polarization did not, however, result in a much needed resolution on the grave human rights abuses in Iraq. As to Cuba, the United States caused the Commission to devote a considerable amount of its time and resources to the human rights situation in that country.

Another new factor was the increased coordination of nongovernmental organizations in making joint statements and otherwise beginning to find ways to improve their contributions to the Commission. 